\title{
Review on Hygienic Milk Products Practice and Occurrence of Mastitis in Cow's Milk
}

\author{
Amanuel Bekuma ${ }^{1 *}$ and Ulfina Galmessa ${ }^{2}$ \\ ${ }^{1}$ Department of Animal Sciences, Mettu University, Ethiopia \\ ${ }^{2}$ College of Agriculture and Veterinary Science, Ambo University, Ethiopia
}

Submission: May 28,2018, Published: October 09, 2018

*Corresponding author: Amanuel Bekuma, Department of Animal Sciences, Bedele College Agriculture and Forestry, Mettu University, P.O.Box 318, Bedele, Ethiopia, Email: amanuelbekuma11@gmail.com

Abstract

Milk is composed of approximately $87.2 \%$ water, $3.7 \%$ fats, $3.5 \%$ protein, $4.9 \%$ lactose $0.7 \%$ ash and has a pH 6.8 . Milk is universally recognized as a complete diet due to its essential nutritional components.Milk is a valuable source of protein, fat, carbohydrates, vitamins and minerals.Milk protein contains all the nine essential amino acids required by humans, especially young ones, for growth and development. The key factor for quality dairy products is to avoid contamination of the raw milk and milk products. Failure to maintain adequate sanitation practices has been contribute to contamination of milk with undesirable or pathogenic micro-organisms or chemical or physical hazards. Because quality of dairy products are easily affected due to different factors of which performance of milking procedures and cleanness of the milking utensils and equipment are the major one. The key sources of contamination are: faeces, from soiled animals, especially teats, udders and tails; bacteria, from poor milking practices, soiled hands, inadequately cleaned and disinfected equipment (including bulk milk tanks), and failure to clean and disinfect teats prior to milking; failure to detect abnormal milk (mastitis pathogens, blood and clots); foreign bodies, especially from perished components in milking machines and bulk tanks, dust, bedding materials, dung, insects and animal hair; chemicals, metals, organics, etc., from veterinary product residues, cleaning chemicals and use of non-food grade equipment.

The common predisposing factors of milk contamination by microorganisms are milking environment, cows, milking personnel, milking equipment, milk transportation and water. On the next milking, the cow is given its calf to suckle and milking follows without cleaning the teats. Saliva from the calf mouth and unwashed teats increase bacterial counts in the milk causing spoilage. Failure to thoroughly clean and dry the udder and teats is a common source of Coliforms in milk. Generally, the milk hygiene practice has interests in preventing the transmission milkborn zoonotic diseases, preventing the transmission of communicable diseases of man through milk, preventing diseases or physical defects that may arise from malnutrition and improving the nutritional status of man in general and of infants, children, and mother in particular. Therefore, as a recommendation, keeping hygienic milk production practices at household level and farm is important for human health.

Keywords: Cow's Milk; Hygiene; Mastitis

\section{Introduction}

Ethiopia holds a substantial potential for dairy development mainly due to its large livestock population coupled with the relatively suitable environment for livestock production [1].With more than 59.5million cattle, 30.70million sheep, 30.20million goats, 2.16 million horses, 8.44 million donkeys, 0.41 million mules, and about 1.21 million camels and 56.53 million poultry, Ethiopia is the largest livestock producer in Africa [2]. The agricultural sector in Ethiopia, engaging $80 \%$ of the population, contributes $52 \%$ of the gross domestic product (GDP) and $90 \%$ of the foreign exchange [3]. The livestock sub-sector alone contributes $12 \%$ of the total and over $45 \%$ of the agricultural GDP, and over $85 \%$ and $90 \%$ of the farm and pastoral incomes, respectively, are generated by or from livestock [4].
Milk is highly nutritious and it is the primary source of nutrition for young mammals before they are able to digest other types of food [5]. It is composed of approximately $87.2 \%$ water, $3.7 \%$ fats, $3.5 \%$ protein, $4.9 \%$ lactose $0.7 \%$ ash and has a $\mathrm{pH} 6.8$ [6]. Milk is universally recognized as a complete diet due to its essential nutritional components [7].The composition of milk makes it an optimum medium for the growth of microorganisms that may come from the interior of the udder, exterior surfaces of the animal, milk handling equipment and other miscellaneous sources such as the air of the milking environment [8]. Milk has nutrients that make it suitable for the rapid multiplication of bacteria that cause spoilage. Unhygienic production, improper handling and undesirable practices such as addition of water 
or other substances can introduce bacteria or germs that cause spoilage [9].

By its nature, milk is an ideal medium for the growth of many microorganisms; and the microorganisms can enter into milk during milking, handling, storage or transportation to the market [10]. The environment, animals being milked, milkers or equipment used in the milking parlor may be the sources of these microorganisms [11]. Once they enter into milk, microorganisms can multiply and cause changes to its quality. If pathogenic microorganisms are involved, they can cause harm to consumers by causing human illnesses and diseases [12]. Because of the specific production, it is impossible to avoid contamination of milk with micro-organisms. Therefore, the microbial content of milk is a major feature in determining its quality [13]. The safety of raw cow milk is influenced by a combination of management and control measures along the entire dairy supply chain. Control of animal health, adherence to good milking practices, and control over milking parlour hygiene are important in reducing the microbial load in raw milk [14]. Dairy animals may carry human pathogens which may increase the risk of causing food borne illness. Moreover, the milking procedure, subsequent cooling and storage of milk carry the risks of further contamination from man or the environment or growth of inherent pathogens [15].

From several types of diseases which potentially infect and affect the wellbeing of livestock population, mastitis is the common and costly disease-causing loss in milk yield and treatment cost for dairy farmers [16]. Mastitis is complex disease that generally involves interplay between management practices and infectious agents, having different extent of intensity and variations in duration and residual effects. There are various infectious agents numbering more than twenty different groups including bacteria, viruses, yeast, fungi and rickettsia [17].Gizat [18], cited that in United States, the economic losses from mastitis have been calculated at approximately 200 dollar/cow/year or 2 billion/year for the nation. In Ethiopia, around urban and peri urban areas of Addis Ababa, Mungube [19], estimated the economic losses from mastitis to be $210.8 \mathrm{birr} / \mathrm{cow} /$ lactation.

Currently in Ethiopia, there is a national drive to alleviate the existing food deficiency by devising different agricultural strategies including improvements of the productivity of livestock sector by controlling some of the major infectious diseases through regular monitoring. Among the infectious diseases in Ethiopia, mastitis plays a high economic impact in the diary sector yet it has been given little attention, especially the sub clinical form which is mainly caused by a bacterial agent called Staphylococcus aureus (S. aureus) [20].Hover, hygienic milk products practice and occurrence of mastitis in cow's milk have not been reviewed earlier and well- documented. Therefore, it is an effort to review the aspect thoroughly and bring minor details into focus to have better understanding of the hygienic milk practices, sources of milk contaminations and risks of mastitis.

\section{Nutritional importance of milk}

Milk is an important source of nutrients required for growth in infants and for maintenance of health in adults. It is a sole natural food for infants [21]. Milk is a valuable source of protein, fat, carbohydrates, vitamins and minerals. Milk protein contains all the nine essential amino acids required by humans, especially young ones, for growth and development. The nine essential amino acids are histidine, isoleucine, leucine, lysine, methionine, phenylalanine, threonine, tryptophan and valine [22]. Milk proteins are required in the body to build and repair tissues and to produce antibodies which circulate in blood and help to resist infection [23]. Some of the minerals found in milk include calcium, magnesium, phosphorus, potassium, selenium, zinc, copper, iron, manganese and sodium. Milk minerals have many uses in the body that include enzyme functions, bone formation, water balance and maintenance of the body and oxygen transport. Milk lactose and fat are good sources of energy whereas milk vitamins play many roles in the body which include being co-factors of metabolism, hormone precursors and antioxidants [21]. Vitamins help the body use carbohydrates, proteins and fats.

\section{Practices of Hygienic Milk Production}

Hygienic production of milk is important for the safety of consumers. In Ethiopia, there is no standard hygienic condition followed by producers during milk production. The hygienic conditions are different according to the production system, adapted practices, level of awareness, and availability of resources [24].

The quality of raw milk has been found to influence the dairy products [25]. The key factor for quality dairy products is to avoid contamination of the raw milk and milk products [26]. Unfortunately, raw milk provides an excellent medium for microorganism growth over a wide temperature range; psychrotrophs bacteria at temperatures below $7^{\circ} \mathrm{C}$, Mesophilic bacteria at 25$37^{\circ} \mathrm{C}$ and Thermophilic bacteria after heating to $60-80^{\circ} \mathrm{C}[27]$. Thus, to ensure food safety and public health, hygiene control is critical and involves feed hygiene, dairy farm practice, dairy processing and not least how consumers handle the milk[28].

Effective handling practice during milking is important and necessary element to produce safe and suitable milk and milk products. Failure to maintain adequate sanitation practices has been shown to contribute to contamination of milk with undesirable or pathogenic micro-organisms or chemical or physical hazards. Because quality of dairy products are easily affected due to different factors of which performance of milking procedures and cleanness of the milking utensils and equipment are the major one [29].Poor hygiene introduces additional bacteria that cause the milk to get spoilt very quickly. To ensure that raw milk remains fresh for a longer time, you need to practice good hygiene during milking and when handling the milk afterwards[30]. Production of quality milk is a complicated process [31]. 
An efficient hygiene program should begin at the farm. Essentially milk hygiene practice has interests in preventing the transmission of disease from animals to man, preventing the transmission of communicable diseases of man through milk, preventing diseases or physical defects that may arise from malnutrition and improving the nutritional status of man in general and of infants, children, and mother in particular [32]. Cleanliness of the premises, personnel, animals and equipment will not only protect public health, by reducing the risk of milk contamination, but also protect the health of the animals, by reducing the risk of mastitis. A reduction in mastitis in the dairy herd also results in improvements in milk quality as measured by the somatic cell count (SCC) in the milk [33].Good quality raw milk must be: free from debris and sediment free from off-flavours, low in bacterial counts, normal composition and acidity, free of antibiotics and chemical residues, safe for human consumption and free from disease producing microorganisms, high in keeping quality, high in commercial value, can be transported over long distances.

Therefore, good hygiene is essential whether the animals are milked by hand or machine [32]. This requires that, the milkers' hands and clothes are clean and he or she is in good health, the milking machine and milk storage equipment such as milk churns are kept clean and are in good condition, immediately after milking, the milk must be cooled preferably to $4^{\circ} \mathrm{C}$. This requires mechanical refrigeration or milk cooling tanks.

\section{Sources of Microbial Contamination of Milk}

Milk can be contaminated at any point in the milk production process. It is the responsibility of the food business operator (milk producer) to identify these points and implement control measures to protect milk from contamination. The key sources of contamination are: Faeces, from soiled animals, especially teats, udders and tails.; Bacteria, from poor milking practices, soiled hands, inadequately cleaned and disinfected equipment (including bulk milk tanks), and failure to clean and disinfect teats prior to milking; Failure to detect abnormal milk (mastitis pathogens, blood and clots);Foreign bodies, especially from perished components in milking machines and bulk tanks, dust, bedding materials, dung, insects and animal hair; Chemicals, metals, organics, etc., from veterinary product residues, cleaning chemicals and use of nonfood grade equipment[34]. The common predisposing factors of milk contamination by microorganisms are milking environment, cows, milking personnel, milking equipment, milk transportation and water [35].

\section{Milking environment}

Maintaining the sanitary condition of the milking area is important for the production of good quality milk [36]. Dirty milking places tend to breed flies, which may fall in milk causing contamination and thus spoilage may occur. When a cow urinatesor defecates in the course of milking some of its urine or dung particles may drop into the milk [35].Microorganisms are mainly transferred from the farm environment to milk via dirt (e.g. faeces, bedding and soil) attached to the exterior of teats; in addition, microorganisms attached to the exterior of the teats can enter the teat canal and cause mastitis [37]. Practices that expose the teat end to organic bedding sources, wet and muddy pens increase the risk of occurrence of mastitis and milk contamination [38].

\section{Cow (udder)}

Cleaning the udder of cows before milking is one of the most important hygienic practices required to ensure clean milk production [36]. This is important since the udder of the milking cows could have direct contact with the ground, urine, dung and feed refusals. Cleaning and removal of soil particles, bedding material and manure from the udder and flanks is necessary to prevent the entry of many types of bacteria into the milk [39]. The exterior of the cows' udder and teats can contribute microorganisms that are naturally associated with the skin of the animal as well as microorganisms that are derived from the environment in which the cow is housed and milked[40].Udder washing with clean water and drying using hand towels reduces milk contamination by transient bacteria located on the udder. Special care must be given to the cloths used for cleaning the udder. The re-use of cloths for cleaning and sanitizing may result in re-contamination of the udder. It is therefore recommended that separate cloths be used for cleaning and sanitizing and, if possible, each cloth should be used for one cow only [39].Not washing the udder before milking can impart possible contaminants into the milk. A maximum reduction of teat contamination of $90 \%$ can be achieved with good udder preparation before milking. This depends on the initial level of contamination and the way of udder preparation. So, with high initial contamination levels this $90 \%$ reduction might not be reached[41].

\section{Milker}

Milk handling personnel (milker) may contribute various organisms including pathogens especially when they are careless, uninformed, or willfully negligent, directly to milk [42]. Organisms may drop from hands, clothing, nose, and mouth and from sneezing and coughing. It is important for milk men to be in good health so that they can be a source of infectious diseases such as tuberculosis [43]. Sterile milk from a normal cow's udder becomes contaminated during milking, cooling, storage and processing. Milking and handling personnel should be healthy and acknowledge the importance of cleanliness. Wet milking should be avoided as organisms present on the milker's hands, cow's teats and udder are washed into the milking utensil contaminating milk and leading to spoilage. Other sources of microorganisms are nasal cavities, mouth, dirty hands, skin and the gastrointestinal tract of both the milker and the animal [35].

\section{Milking equipment}

Poorly cleaned and sanitized milking utensils may be the source of many microorganisms [43]. Milk drops left on the surface 
of milking equipments act as excellent media for the growth of a variety of bacteria $[44,45]$. Milk equipment is not properly cleaned and sanitized after use. Milk residues left on equipment and utensil surfaces provide nutrients to support the growth of many microorganisms, including pathogens [46]. In case cracked milking equipments large number of bacteria enter and grow in the cracks, are difficult to clean [47]. The bacterial load of milk increases during transportation and if the transportation equipment is not appropriate the bacterial counts increase causing spoilage before milk reaches its destination [48]. Milking equipment should be easy to clean. Aluminum and stainless steel equipment are mostly preferred [36].

\section{Water}

Water serves as primary sources of microorganism's contamination [35]. If Water is obtained from an open water supply care should be taken to prevent drainage that may contain human feces and other contaminants gaining entry into the source[49].

\section{Control of milk spoilage}

Milk is a bulky product containing more than $80 \%$ water and is difficult to transport. It has a short storage life and must be consumed immediately unless it is processed to other products it deteriorates very fast [50]. Previous researches have indicated presence of coliforms in milk at farm level but these have been controlled by chilling temperatures and totally destroyed at pasteurization temperatures [48].Milk quality across the value chain could be improved through; changing milking practices to ensure better hygienic conditions, improvement of milk handling and improvement of storage conditions maintaining the cold chain [35]. Milk should therefore be cooled to $4^{\circ} \mathrm{C}$ and transported in insulated trucks for quality delivery [35]. Planners should consider the relative efficiency of alternative milk marketing systems in terms of costs and marketing margins, product hygiene and quality range to avoid losses due to spoilage [35].

For production of quality milk a good supply of clean cold water is essential. Water used in washing and rinsing milk equipments and containers for handling milk must be of the same safety and purity as drinking water. If water is obtained from an open water supply, care should be taken to prevent drainage that may contain human feces and other contaminants gaining entry into the source. Milk should be handled in containers which are made of seamless stainless steel without cracks where bacteria can lodge and multiply leading to spoilage and these containers should be unaffected by milk or by chemicals used in cleansing. Poorly cleaned and sanitized milking utensils may be the source of many microorganisms which transform high quality milk to an unacceptable product; therefore, thoroughly cleaned utensils should be used to handle milk [44].

Milking cows should be kept clean, groomed every day and the udders and teats thoroughly washed before every milking as the coat and skin are always dirty as this could act as a source of spoilage bacteria [51]. Dampening of the milking parlor floor prior to milking is an effective method of preventing dust from rising. This floor should he solid, well drained, kept clean and manure should he kept as far as possible from the milking places as these could be sources of contaminants causing milk spoilage.

Personnel connected with the milking and handling of milk should be healthy and should acknowledge the importance of cleanliness by wearing clean overalls and wash hands with soap and clean water prior to milking [35]. Wet milking should be avoided as organisms present on the milker"s hands, teats and udder of the cow are washed into milking utensil contaminating the milk and leading to spoilage [35]. Before milking, excess water on the udder should be cleaned with a clean cloth or udder towel and the first draw of milk should be collected into a strip cup to exclude mastitis milk from mixing with normal milk as this will limit spoilage [30]. Milk should be transferred between containers by pouring and not scooping since this may introduce spoilage bacteria into the milk and delivery of milk to collecting centres and processing plants shall be within three hours of milking to avoid deterioration [30]. Excessive shaking of milk should be avoided during transportation and this is achieved by minimizing the head space when filling the containers and these containers should not be kept under direct sunlight [30].

\section{Milking Practices}

Udder washing before milking should be regarded as a means of removing dirt but not eliminating bacteria from the cows" skin [51]. According to Mbabazi[35], most farmers do not wash the udder of their cows before milking; they assume allowing the calf to suckle before milking is sufficient to clean the teats. Sometimes the teats are smeared with cow dung after milking as a means of preventing calves from suckling the dam while grazing [52]. On the next milking, the cow is given its calf to suckle and milking follows without cleaning the teats. Saliva from the calf mouth and unwashed teats increase bacterial counts in the milk causing spoilage. Failure to thoroughly clean and dry the udder and teats is a common source of Coliforms in milk [51].

\section{Cooling of Milk}

Effective milk cooling is essential to ensure the quality of the product. If the milk is cooled to $4^{\circ} \mathrm{C}$ within a period of $2-3$ hours after milking, it maintains nearly its original quality and remains good for processing and consumption. However, in rural areas it is hardly possible to achieve this. Simple alternatives are putting the container with milk in water or placing a moist cloth around the metallic milk containers. Other possibilities are solar powered coolers or a charcoal box which is moistened to reduce the milk temperature [31]. In the tropical countries of Africa with high ambient temperatures, lack of refrigeration facilities at the farm and house hold level imply that raw milk will acidify very fast unless and otherwise protected. Therefore, the collection systems must be designed to move the milk to the cooling and/ or processing center in shortest possible time. In addition, every 
effort should be made to use available systems such as water cooling, air circulation or shaded areas to reduce milk temperature [53].

\section{Storage of Raw Millk}

Having limited the number of bacteria entering milk during milking, it is essential that contamination from equipment situated between the cow and the refrigerated storage unit is kept to a minimum. Bacteria are present in the air, dust and water, especially any water containing traces of milk residues which may have been left in the milking plant overnight, as such residues provide a very good source of food for bacteria, thereby enabling the bacterial counts to increase rapidly. Cleaning regimes are based on removing visible dirt, removing milk residues (fat, protein, milk stones) which harbour bacteria, then sterilization of the cleaned surfaces using heat or chemical sterilants such as sodium hypochlorite [40].In tropical conditions, raw milk, i.e. nonpasteurized milk, goes off within a few hours. It must therefore be kept cool and quickly pasteurized and again cooled to a temperature of $4^{\circ} \mathrm{C}$ if possible [54].

\section{Housing Conditions}

Maintaining the sanitary condition of barn is important for the production of good quality milk. Clean, dry and comfortable bedding condition is important to minimize the growth of pathogenic microorganisms. [55]. Proper and clean housing environment is a prerequisite to produce milk and milk products of acceptable quality [56].In temperate regions, cows are housed in winter and pastured in summer. Differences in teat contamination can be found between housing and pasturing. Both total plate and aerobic spore counts are lower when cows are at pasture. When cows are housed, bedding material and feed stuffs can be contamination sources. In both cases (housing and pasturing) feces and dung are also an important contamination sources. Contamination of bedding material can be very high due to absorption of urine and feces [53].

\section{Mastitis}

Mastitis is an inflammation of the udder. In cows, inflammation of the udder is almost always caused by harmful bacteria, which enter through the teat end and set up infection. Although a bacterial infection is the root cause, and mastitis or inflammation the effect or outcome, we tend to use the words 'mastitis' and 'infection' interchangeably. This is because preventing mastitis involves preventing bacterial infections [57]. Mastitis is defined as an inflammatory reaction of the mammary gland. It is induced when pathogenic microorganisms enter the udder through the teat canal, overcome the cow's defense mechanisms, begin to multiply in the udder, and produce toxins that are harmful to the mammary gland. Mammary tissue is then damaged, which causes increased vascular permeability. As a result of this, milk composition is altered: there is leakage of blood constituents, serum proteins, enzymes, and salts into the milk; decreased synthesis of caseins and lactose; and decreased fat quality [58].

\section{Causes of Mastitis}

Bovine mastitis is associated with many different infectious agents, commonly divided into those causing contagious mastitis, which are spread from infected quarters to other quarters and cows, those that are normal teat skin inhabitants and cause opportunistic mastitis, and those causing environmental mastitis, which are usually present in the cow's environment and reach the teat from that source [59]. Mastitis, an inflammatory reaction of the mammary gland caused by bacterial infection or tissue trauma [60], is the most common and economically costly disease in dairy farming [61]. It is a multifactorial disease, affected by management practices, exposure to pathogens and efficiency of the udder defense mechanisms as well as interaction between these factors [62]. The most common route for pathogenic microorganisms to enter the udder is through the teat canal.The subsequent damage to the tissue of the mammary gland increases the vascular permeability and results in an increased number of somatic leukocyte cells in the milk [63].

Dirty bedding constitutes a hygiene risk to udder health [64], and it was also reported that suckling improves udder health in suckled compared to non-suckled cows, probably due to improved udder emptying [65], Milk always contains a certain amount of somatic cells of various types, and their relative proportion depends on the health status of the cow [63]. Mastitis can be classified as acute or chronic, depending on the duration of the infection, and is further classified as clinical or subclinical.In subclinical mastitis, the udder and milk show no visible signs of inflammation, whereas clinical mastitis does, including redness, heat, pain and impaired function [66].

\section{Diagnosis of Mastitis using California Mastitis Test (CMT)}

Table 1: Interpretation of CMT score.

\begin{tabular}{|c|c|c|}
\hline CMT Score & Somatic Cell Range & Interpretation \\
\hline N (Negative) & $0-200,000$ & Healthy Quarter \\
\hline T (Trace) & $200,000-400,000$ & Subclinical Mastitis \\
\hline 1 & $400,000-1,200,000$ & Subclinical Mastitis \\
\hline 2 & $1,200,000-5,000,000$ & Serious Mastitis Infection \\
\hline 3 & Over $5,000,000$ & Serious Mastitis Infection \\
\hline
\end{tabular}

California Mastitis Test (CMT) [66], somatic cell count in milk $[67,68]$, lactose and lactate dehydrogenase content [69], are all used as indication methods for udder health status and mastitis. The California mastitis test is most commonly used and has proved to be very efficient, after mixing milk and the reagent the result is read as traces, 1,2,3, and negative depending up on the gel formation in the milk sample [70]. The CMT solution reacts with leukocytes and forms a gel [66], and the test is quick and easy to apply on farm. There is still discussion on the levels of SCC that indicate a mastitis risk. Harmon [64], showed that above 200,000 cells/ml milk per cow, the risk for mastitis was increased, while 
others have suggested that SCC in milk from a healthy udder should be below 100,000 cells/ml milk [71], and some authors have even mentioned 50000 cells/ml per udder quarter [72]. It is well known that good environmental hygiene [64], cleanliness of dairy cows, washing and dipping teats after milking and good milking routines are important for ensuring udder health. Clean bedding, the housing system and stocking density are also important(Table 1)[73].

\section{Consequences of Mastitis for Milk Production}

Mastitis is a serious disease for the dairy industry causing economic losses for farmers [61]and impacting cow welfare. Clinical mastitis is associated with milk yield loss at the time of diagnosis and throughout lactation. Lactation yield losses of 4 to $6 \%$ in multiparous cows and 2 to $4 \%$ in primiparous cows have been reported [74]. However, Wilson et al. [75], show that, before diagnosis, mastitic cows have a production advantage over nonmastitic cows. Clinical mastitis also leads to decreased milk casein, lactose and fat content [74].

Financial loss involved as a result of permanent loss of production in individual cows, discarded milk following antibiotic therapy, early culling of cows, veterinary costs, drug costs, increased labor, death of per acute cases and replacement costs[76]. In Ethiopia, the aggregate annual economic losses from animal diseases through direct mortality and reduced productive and reproductive performance were estimated at US $\$ 150$ million [77]. Economic losses from clinical and subclinical mastitis in Addis Ababa milk shed were reported to be approximately 270 Ethiopian birr (ETB) per lactation [76]. Gizat [18], reported the economic loss from mastitis in the urban and peri urban areas of Addis Ababa. The report was based on milk production losses, treatment costs, withdrawal and culling losses as parameters for calculating losses. This loss was found to be 210.8 birr per cow per lactation.

\section{Risk factors influencing Prevalence of Mastitis}

There are a number of factors that influence the occurrence of mastitis and fewer studies that have investigated cow-level factors associated with the development of Clinical mastitis was carried out. The risk of developing Clinical mastitis is greatest in early lactation and increases with parity and level of milk production [78]. They have also reported that the risk of a cow developing in the subsequent month of lactation is also a function of number of cases of Clinical mastitis in the previous lactation, number of clinical cases in the previous months of the current lactation, and the occurrence of Clinical mastitis in the current month. The risk of contracting Clinical mastitis was 4.8 times greater if the animal experienced Clinical mastitis in the previous stage of lactation. Clinical mastitis occurred in 38\% of cows that experienced Clinical mastitis in the previous lactation, as opposed to $23 \%$ of those that had not [78].

The prevalence of infected quarters increases with age, peaking at 7 years [59]. It may also be a result of a greater cellular response to infection or of a greater amount of permanent udder damage after infection in older cows. Older cows, especially after four lactations were submitted to more lactation, increasing the risk for mastitis and udder tissue damage [58]. Most new infections occur during the early part of the dry period and in the first 2 months of lactation, especially with the environmental pathogens [59]. Christa [58], reported that the first month of lactation is the most sensitive period for risk of mastitis in the cow, even in well managed herds. On the other hand, the SCC of cows late in lactation is higher than the average throughout lactation, but this is due to an increased prevalence of sub-clinical infections late in lactation and a reduced milk flow production.

Predisposing factors such as poor management and hygiene, teat injuries and faulty milking machines are known to hasten the entry of infectious agents and the course of the disease [79]. Where predisposing factors are present the organisms are able to pass along the teat canal and enter udder the set-up infection. These factors may be age (the older the animal the greater the likelihood of the infection), stage of lactation (more likely at the beginning of and the end of lactation), milk yield (high yielder), hereditary factors, trauma, hygiene and unknown factors [70].

\section{Control of mastitis}

Experiences in attempts to control mastitis indicate that while the occurrence of inflammation in the udder may not be entirely preventable in all cows, the frequency of appearance among cows with in a herd and the intensity of clinical attacks may be lessened significantly through better management [80].According to Radostits et al. [59], Components of Mastitis Control Program includes, use proper milking management methods, Proper installation, function, and maintenance of milking equipment, Dry cow management[81-95].Appropriate therapy of mastitis during lactation, Culling chronically infected cows, Maintenance of an appropriate environment, Good record keeping, Monitoring udder health status, Periodic review of the udder health management program and Setting goals for udder health status [95-110].

\section{Conclusion and Recommendations}

Since milk contaminants are derived from improper management of milk and milk product during milking, handling, storing and transporting to the market place, the hygienic conditions of cow's milk should be maintained at all household and farm level through practicing hygienic condition of the milking environment, sanitation of the milk containers, udder and teats cleaning, use of separate towel for each cow and the personal hygiene of the milkers are fully performed. Good milk handling practice reduces milk contaminations and so in that way it enables to eliminate harmful microorganisms and reduce the risks of mastitis.

\section{References}

1. Bereda A, Yilma Z, Nurfeta A (2014) Dairy Production System and Constraints in Ezha Districts of the Gurage Zone Southern Ethiopia. Global Veterinaria 12(2): 181-186. 
2. CSA (2017) Agricultural sample survey $2016 / 2017$ on livestock and livestock characteristics. Central Statistics Authority. Addis Ababa, Ethiopia.

3. Aynalem H, Workneh A, Noah K, Tadelle D, Azage T (2011) Breeding strategy to improve Ethiopian Boran cattle for meat and milk production. IPMS (Improving Productivity and Market Success) of Ethiopian Farmers Project Working Paper 26. Nairobi, Kenya, ILRI. p. 1.

4. MOARD (Minister of Agricultural Rural Development) (2005) Agricultural marketing strategy, Addis Ababa, Ethiopia.

5. Bankole AA, Secka A, Ly C (2011) Risk behaviors for milk-borne diseases transmission along the milk chain in The Gambia and Senegal. Journal of Tropical Animal Health and Production 43(1): 103-109.

6. Olatunji EA, Jubril AE, Okpu EO, Olafadehan OA, Ijah UJ, et al. (2012) Bacterial Assessment and Quality Analysis of Raw Milk Sold in Gwagwalada Area Council of the Federal Capital Territory (FCT) Abuja, Nigeria. Food Science and Quality Management 7: 1-4.

7. Benta D, Abtamu T (2011) study on Prevalence of Mastitis and its Associated Risk Factors in Lactating Dairy Cows in Batu and its Environs, Ethiopia, Global veterinaria 7(6): 632-637.

8. Worku T, Negera E, Nurfeta A, Welearegay H (2012) Microbiological quality and safety of raw milk collected from Borana pastoral community, Oromia Regional State. Afr J Food Sci Technol 3(9): 213-222.

9. Paul G, Angela W, Brian D (2004) Training guide for small-scale informal milk traders peri-urban dairy shed of the central Ethiopia. DEA. Lyon, France.

10. Garedew L, Ayalew Berhanu, Desalegne Mengesha, Getachew Tsegay (2012) Identification of gram-negative bacteria from critical control points of raw and pasteurized cow milk consumed at Gondar town and its suburbs, Ethiopia. BMC 12: 950.

11. Gran HM, Mutukumira AN, Wetlesen A, Narvhus JA (2002) Smallholder dairy processing in Zimbabwe: hygienic practices during milking and the microbiological quality of the milk at the farm and on delivery. Journal of Food Control 13: 41-47.

12. Barros LSS, Sóglia SLO, Ferreira MJ, Rodrigues MJ, Branco MPC (2011) Aerobic and anaerobic bacteria and Candida species in crude milk. Journal of Microbiology and Antimicrobials 3(8): 206-212.

13. Karmen GT, Slavica GT (2008) The Microbiological Quality of Raw Milk After Introducing. The two Day's Milk Collecting System. Acta agriculturae Slovenica 92(1): 61-74.

14. Food Standards Agency (FSA) (2006) Milk hygiene on the dairy farm a practical guide for milk producers to the food hygiene (England) and to food hygiene (whale): pp. 1-10.

15. Codex Alimentarius Commission (CAC) (2004): Code of hygienic practices for milk and milk products. pp. 4 .

16. Nibret M, Hailemariam T, Fentahun T, Chanie M, Melaku A (2012) Bovine Mastitis and Associated Risk Factors in Small Holder Lactating Dairy Farms in Hawassa, Southern Ethiopia. Global Veterinaria 9(4): 441-446.

17. Lidet G, Deressa B, Begna F, Mekuria A (2013) Study on prevalence of bovine mastitis in lactating cows and associated risk factors in and around Areka town, Southern of Ethiopia. African journal of microbiology research 7(43): 5051-5056.

18. Gizat A (2004) A Cross-sectional Study of Bovine Mastitis in and Around Bahir Dar and Antibiotic Resistance Patterns of Major Pathogens.

19. Mungube EO (2001) Management and economics of dairy cow mastitis in the urban and peri urban areas of Addis Ababa (Addis Ababa milk shed), Faculty of Veterinary Medicine, Addis Ababa University, Ethiopia, Debre Zeit, MSc Thesis.
20. Aberra B, Lemma D and Iticha I (2013) Study of bovine mastitis in assella government dairy farm of Oromia Regional state, South Eastern Ethiopia international journal of current research and academic review. Int J Curr Res Aca 1(2): 134-145.

21. Boor KJ, Brown DP, Murphy SC, Kozlowski SM, Bandler DK (1998) Microbiological and Chemical Quality of Raw Milk in New York State. J of Diary Sci 81(6): 1743-1748.

22. Huth PJ, DiRienzo DB, Miller GD (2006) Major Scientific Advances with Dairy Foods in Nutrition and Health. Journal of Dairy Science 89(4): 1207-1221.

23. Javaid SB, Gadahi JA, Khaskeli M, Bhutto MB, Kumbher S, et al. (2009) Physical and Chemical Quality of Market Milk Sold at Tandojam, Pakistan. Pakistan Vet J 29(1): 27-31.

24. Zelalem YK (2003) Sanitary Conditions and microbial qualities of dairy products in urban and peri-urban dairy shed in the Ethiopian central highlands. EIAR DSpace. p. 43.

25. Schroeder W, Ruminski M, Csiszar I, Giglio L, Prins E, et al. (2008) Validation analyses of an operational fire monitoring product: The Hazard Mapping System. International Journal of Remote Sensing 29(20): 6059-6066.

26. Elmoslemany AM, Keefe GP, Dohoo IR, Dingwell RT (2009) Microbiological quality of bulk tank raw milk in Prince Edward Island dairy herds. Journal of Dairy Science 92(9): 4239-4248.

27. Paulo Batista de Oliveira, Alice Eiko Murakami, Elis Regina de Moraes Garcia, Marcos Macari, Cláudio Scapinello (2000) Influência de Fatores Antinutricionais da Leucena (Leucaena leucocephala e Leucaena cunningan) e do Feijão Guandu (Cajanus cajan) Sobre o Epitélio Intestinal e o Desempenho de Frangos de Corte. Rev Bras Zootec 29(6): 17591769.

28. Valeeva NI, Miranda PM Meuwissen, Ron HM Bergevoet, Alfons GJM Oude Lansink, Ruud BM Huirne (2005) Improving Food Safety at the Dairy Farm Level: Farmers' and Experts' Perceptions. Review of Agricultural Economics 27(4): 574-592.

29. Gonfa A, Howard AF, Wilhelm HH (2001) Field survey and literature review on traditional fermented milk products of Ethiopia, International Journal of Food Microbilogy 68(3): 173-186.

30. Lore TA, Kurwijila LR, Omore A (2006) Hygienic milk production: a training guide for farm-level workers and milk handlers in Eastern Africa. Nairobi (Kenya): ILRI, CGSpace.

31. Pandey GS, Voskuil GCJ (2011) Manual on improved feeding of dairy cattle by smallholder farmers. golden valley agricultural research trust. p. 52.

32. Barbuddhe SB, Swain BK (2008) Hygienic Production of Milk. Technical Bulletin No: 11, ICAR Research Complex for Goa (Indian Council of Agricultural Research), Ela Old Goa- 403 402, Goa, India: pp. 1-4.

33. Buncic S, (2006) Integrated food safety and veterinary public health School of Veterinary Science University of Bristol, UK: pp. 283-287.

34. FSA (2013) Milk hygien on the dairy farm.

35. Mbabazi P (2005) Milk industry in Uganda, $1^{\text {st }}$ (edn), Fountain Publishers Kampala, medicine. $10^{\text {th }}$ (edn), A textbook of the diseases of cattle, horses, sheep, pigs and goats, Meeting Proceedings. pp. 11.

36. Zelalem Yilma, Emmannuelle Guernebleich, Ameha Sebsibe (2011) Quality factors that affect Ethiopian milk business: Experiences from zone, Ethiopia. MSc. thesis Haramaya university, Ethiopia.

37. Driehuis F, Vissers MMM, Slaghuis BA, Giffel MC (2008) Contamination of raw milk with aerobic bacterial spores via the milking equipment. Cork, Ireland: Teagasc International Symposium on advances in milking, pp. 119-120. 
38. Ruegg LP (2006) Role of hygienic in efficient milking. WCDS advances in Dairy Technology. p. 9.

39. O'Connor CB (1995) Rural Dairy Technology. ILRI Training Manual No.1. International of dairy cows depends on cubicle adjustment. Journal of Animal Science 82: 3321-3337.

40. Nangamso BC (2006) General hygiene of commercially available milk in the Bloemfontein area. pp. 127.

41. Murphy SC (1996) Sources and Causes of High Bacteria Count in Raw Milk: An Abbreviated Review. National printers Ltd, Singapore.

42. Ashenafi Mengstu (1994) Microbial load, microflora, and keeping quality of raw and pasteurized milk from a dairy farm. Bulletin Animal Health Production Africa 42: 55-59.

43. Kurwijila LR (1989) Technology of Traditional Milk Products in Developing Countries; Southern and Eastern Africa, FAO. pp. 221.

44. Banwart GJ (1989) Basic Food Microbiology, $2^{\text {nd }}$ (Edn), Van Nostr and Reinhold, New York, USA.

45. Bramley AJ, McKinnon CH (1990) Microbiology of raw milk. Dairy Microbiology 1. Elsevier Science Publishers, London, pp: 163-208.

46. Bryan FL (1983) Epidemiology of milk-borne diseases. Journal of Food Protection 46(7): 637-649.

47. Thomas SB, Druce RG, King KP (1966) The microflora of poorly cleansed farm dairy equipment. J Appl Bacteriol 29(2): 409-422.

48. Grillet N, Grimaud P, Sserunjogi ML (2007) African Journal of Food, Agriculture, Nutrition and Development, Issue 16(7).

49. Jay MJ (1992) Modern Food Microbiology, $4^{\text {th }}$ (Edn), Van Nostrand Reinhold, New Karmen, Springer.

50. Matthewman Richard W, Noël Chabeuf (1993) Dairying; The Tropical Agriculturalist (1 ${ }^{\text {st }}$ Edn), Macmillan, London, UK, pp. 152.

51. Barret, Larkin (1979) Milk and Meat Production in the Tropics, $1^{\text {st }}$ (Edn.) Oxford.

52. Bekele E (1989) Technology of traditional milk products of the Peoples" Democratic Republic of Ethiopia and The Republic of Mali. FAO Manuscript.

53. Alehegne W, Bayeleyegn M, Kelay B (2009) Bacteriological quality of bovine milk produced by smallholder dairy farms in Debre Zeit, Ethiopia. Bulletin of Animal Health and Production in Africa 57(1).

54. Pauline E, Karin R (2006) Preparation of dairy products. CTA, Wageningen, Netherlands, p. 87.

55. Gurmessa T (2015) Microbiological quality and impact of hygienic practices on raw cow's milk obtained from pastoralists and market. The case of Yabello District, Borana zone, Ethiopia. Global Journal of Food Science and Technology: 153-155.

56. Asaminew T (2007) Production, handling, traditional processing practices and quality of milk in Bahir Dar milk shed area, Ethiopia. Haramaya University of Agriculture, Dire Dawa, Ethiopia.

57. Livestock improvement (LI) (2001) managing mastitis. 3RD ED, A practical guide for New Zealand dairy farmers, New Zealand, p. 9.

58. Christa P (2008) The effect of coryne bacterium cutis lysate to control somatic cell counts in dairy cows, Dissertation submitted in accordance with the requirements for the degree Magister Scientiae Agriculturae to the Department of Animal, Wildlife and Grassland Sciences Faculty of Natural and Agricultural Sciences University of the Free State Bloemfontein pp. 25-26.

59. Radostits OM, Gay CC, Hinchcliff KW, Constable PD (2006) Veterinary Medicine: A Textbook of the Diseases of Cattle, Horses, Sheep, Pigs and Goats. $10^{\text {th }}(\mathrm{edn})$, Elsevier Saunders, London, pp. 966-994.
60. Harding F (1999) Milk quality Editorial Service: Ruth Bloom, Library of Congress Catalog. pp. 166.

61. Nielsen C (2009) Economic Impact of Mastitis in Dairy Cows. Doctoral Thesis Swedish, Uppsala, p. 81.

62. Oviedo-Boyso J, Valdez-Alarcon JJ, Cajero-Juarez M, Ochoa-Zarzosa A, Lopez-Meza JE, et al. (2007) Innate immune response of bovine mammary gland to pathogenic bacteria responsible for mastitis. J Infect 54(4): 399-409.

63. Harmon RJ (1994) Physiology of mastitis and factors affecting somatic cell counts. J Dairy Sci 77(7): 2103-2112.

64. Barberg AE, Endres MI, Salfer JA, Reneau JK (2007) Performance and welfare of dairy cows in an alternative housing system in Minnesota. J Dairy Sci 90: 1575-1583.

65. Fröberg S (2008) Effect of Restricted and Free Suckling. In Cattle used in Milk Production Systems. Doctoral Thesis No. 2008:99, Faculty of Veterinary Medicine and Animal Science.

66. Marshall RT, Edmonson JE, Steevens B (1993) Using the california mastitis test. University of Missouri Extension.

67. Berglund J (2003) Milking Dairy Cows at Udder Quarter level. Possibilities and Application, Licentiate thesis. Report 255. Swedish University of Agricultural Sciences, Uppsala, Europe.

68. Berglund J, Pettersson G, Östensson K, Svennersten Sjaunja K (2007) Quarter Milking for Improved Detection of Increased SCC. Reproduction in Domestic Animals 42: 427-432.

69. Friggens NC, Chagunda MGG, Bjerring M, Ridder C, Højsgaard SP, et al. (2007) Estimating Degree of Mastitis from Time-Series Measurements in Milk: a test model based on lactate dehydrogenase measurements. J Dairy Sci 90: 5415-5427.

70. Indian council of agricultural research (ICAR) (2011) Handbook of animal husbandry. $3^{\text {rd }}$ (edn), New Delhi, pp. 520-522.

71. Forsbäck L, Lindmark Månsson H, Andrén A, Åkerstedt M, Svennersten-Sjaunja, K. (2009). Udder quarter milk composition at different levels of somatic cell count in cow composite milk. Animal 3(5): 710771.

72. Merle R, Schröder A, Hamann J (2007) Cell function in the bovine mammary gland: a preliminary study on interdependence of healthy and infected udder quarters. J Dairy Res 74(2): 174-179.

73. Veissier I, Capdeville J, Delval E (2004) Cubicle housing systems for cattle: Comfort Cubicle housing systems for cattle: Comfort of dairy cows depends on cubicle adjustment. J Anim Sci 82(11): 3321-3337.

74. Hortet P, Seegers H (1999) Loss in milk yield and related composition changes regulating from clinical mastitis in dairy cows. Prev Vet Med 37(1-4): 1-20.

75. Wilson DJ, Gonzalez RN, Hertl JA, Schulte HF, Bennett GJ, et al. (1989) Conducting on-farm animal research: Procedures and economic analysis. work shop on small holder dairy production and marketing, constraints and opportunities.

76. Sisay G, Mammo A, Bogele K, Sori T, Tadesse F, et al. (2012) Study on Somalia: Limiting factors and development potential. CH-8092 Zurich, Switzerland.

77. Belay D, Kechero Y, Janssens PJ (2012) Survey of Major Diseases Affecting Dairy Cattle in Jimma Town, Oromia, Ethiopia Global Veterinaria 8(1): 62-66.

78. Berry DP, Meaney WJ (2005) Cow factors affecting the risk of Clinical mastitis Irish J. Agri and Food Res 44: 147-156.

79. Islam MA, Islam MZ, Islam MA, Rahman MS, Islam MS (2011) Prevalence of subclinical mastitis in dairy cows in selected areas of Bangladesh. Bangl J Vet Med 9(1): 73-78. 
80. Fincher MG, Gibbons WJ, Mayer K, Park SE (2001) Diseases of cattle, A text book and reference work, India. pp. 302-325.

81. England Garedew L, Berhanu A, Mengesha D, Tsegay G (2012) Identification of gram-negative bacteria from critical control points of raw and pasteurized cow milk consumed at Gondar town and its suburbs, Ethiopia. Journal of Public Health 12: 950-953.

82. RLDC (2009) Rural livelihood development company. Dairy sub sector in sub Saharan Africa. Controlling Contagious Mastitis National Mastitis Council Regional.

83. Ahmed M, Ehuis AM, Assefa Y (2004) Dairy development in Ethiopia. Environment and production technology division. International food policy research institute, 2033 Street, NW Washington.

84. Asrat A, Zelalem Y, Ajebu N (2014) Production, utilization and marketing of milk and milk products: Quality of fresh whole milk produced in and around Boditti, Wolaita, South Ethiopia. pp. 75-76.

85. Asrat (2013) Characterization of milk production systems in and around Boditti, South Ethiopia. Livestock Research for Rural Development 25(10).

86. Asrat (2015) Dairy Cattle Production Systems in Humbo Woreda Wolaita Zone, Southern Ethiopia. Journal of Biology Agriculture and Healthcare 5 .

87. Central Statistics Agency (2011) Report on Livestock and Livestock Characteristics, Agricultural Sample Survey 2, Statistical Bulletin 505, Federal Democratic Republic of Ethiopia.

88. CSA (Central Statistics Authority) (2010) Agricultural sample survey. Report on crop and livestock product utilization. The Federal Democratic Republic of Ethiopia, Central Statistical Agency (CSA). Private Peasant Holdings. Statistical Bulletin 468, Addis Ababa, Ethiopia dairy equipment. Journal Applied Bacteriology 29: 409.

89. Debrezeit, Ethiopia, an MSC Thesis Submitted to the Faculty of Veterinary Medicine, Addis Ababa University in Partial Fulfillment of the Requirement of the Degree of Master of Science in Tropical Veterinary Medicine: pp. 2-13.

90. EPTD Discussion International Food Policy Research Institute, NW Washington, estimation using daily milk weight. Journal of Dairy Science 87: 2073-2084.

91. Ethiopian Dairy Sector, FAO Sub Regional Office for Eastern Africa (FAO/SFE). extension workers and dairy farmers, Lusaka, Zambia, pp. 7-26.

92. FAO (2004) Livestock sector in brief in Ethiopia. Food and Agriculture organization of the United Nations. Livestock information, sector analysis and policy branch. AGAL.

93. Hemme T, Otte J, Rome (2010) FAO (Food and Agriculture Organization) Status and prospects for smallholder milk production: A global perspectiv.

94. Gebrekidan T (2014) Dairy Cattle Production System in Central Zone of Tigray: in The Case. Global Journal of Animal Scientific Research: 151158
95. Gröhn YT (2004) Effect of clinical mastitis on the lactation curve: a mixed model a mixed model estimation using daily milk weights. J Dairy Sci 87(7): 2073-2084

96. Haese MD, Francesconi GN, Ruben R (2007) Network management for dairy productivity and quality in Ethiopia development economics groups, Wageningen Unvirsity, Hollandseweg 1,6706 KN, Wageningen, the Netherlands.

97. Islam MA, Rahman AKM, Rony SA, Islam MS (2010) Prevalence and risk factors of mastitis in lactating dairy cows at Baghabari milk shed area of Sirajganj. Bangl J Vet Med 8(2): 157-160.

98. Karmen GT, Slavica GT (2008) The microbiological quality of raw milk after introducing the two day's milk collecting system. Acta agriculturae Slovenica 92(1): 61-74.

99. Ketema, Tsehay (2014) Strategies for market orientation of small-scale milk producers and their Ethiopia: Agriculture and Consumer Protection.

100. Ketema S (2008) Characterization of market-oriented smallholder dairying and performance evaluation of dairy cooperatives in Tiyo Woreda, Arsi Zone of Oromia Regional State. Hawassa University, Hawassa, Ethiopia.

101. Mohammed AM, Ehui S, Yemeserach Assefa (2004) Dairy Development in Ethiopia. Int Food P Res inst. p. 58

102. Mungube EO (2001) Management and economics of dairy cow mastitis in the urban and peri urban areas of Addis Ababa (Addis Ababa milk shed), Faculty of Veterinary Medicine, Addis Ababa University, Debre Zeit, MSc Thesis.

103. Muriuki HG, Thorpe W (2001) Smallholder dairy production and marketing, constraints and opportunities. pp. 206-247.

104. Prain G, Karasna N, Simth D (2010) African union harvest agriculture in the cities of prevalence of bovine mastitis and its major causative agents in West Harerghe zone.

105. Quinn PJ, Carter ME, Markey B, Carter GR (2004) Clinical Veterinary Microbiology. Elsevier Ltd. pp. 684.

106. Redda T (2001) Small scale milk marketing and processing in Ethiopia. In proceedings of south report of work shop held on 3-5 March 2003 in Nairobi Kenya. Natural resource Ltd. pp. 352-365.

107. Saba H (2015) Quality assessment of cattle milk in Adea berga and Ejere districts of West Shoa Zone, Ethiopia. MSc in Agriculture (Animal Production). Haramaya, Ethiopia.

108. Tsegay Lijalem Gebreegziabher Z (2015) Hygienic Milk Handling and Processing at Farmer Level in Wolaita Zone, Southern Ethiopia. Food Science and Quality Management, pp. 152-159.

109. Vikas Choudhary, Anton Van Englen, Sebadduka Sam, Pablo Valdivia (2011) Uganda bovine mammary gland to pathogenic bacteria responsible for mastitis. Journal of Cameron, Kenya and Uganda. international development research center. pp. 335.

110. Livestock Research Institute (ILRI), Addis Ababa, Ethiopia. London UK, pp. 674-676. 
This work is licensed under Creative Commons Attribution 4.0 License DOI: 10.19080/ARTOAJ.2018.18.556053

\section{Your next submission with Juniper Publishers will reach you the below assets}

- Quality Editorial service

- Swift Peer Review

- Reprints availability

- E-prints Service

- Manuscript Podcast for convenient understanding

- Global attainment for your research

- Manuscript accessibility in different formats

( Pdf, E-pub, Full Text, Audio)

- Unceasing customer service

Track the below URL for one-step submission https://juniperpublishers.com/online-submission.php 